\title{
Application of Philosophy Values of Bhinci-Bhinciki Kuli in Early Childhood at Wolio Community
}

\author{
La Jeti ${ }^{1}$, Manan ${ }^{2}$ Kadar Risman ${ }^{3}$ Edison $^{4}$ \\ Pendidikan Anak Usia Dini, Universitas Muhammadiyah Buton \\ DOI: $10.31004 /$ obsesi.v5i1.643
}

\begin{abstract}
This research aimed to describe the application the philosophy values of Bhinci-bhinciki Kuli in early childhood at Wolio community. This research used descriptive method with ethnographic approach. The subjects of this research consisted of the chiefs. This research was conducted at wolio community In Buton. Method of data collection used observation and interviews. Based on the results of data analysis, showed that: The values of Bhinci-bhinciki Kuli included Poma-masiaka which means mutual love, Poangka-kataka which means mutual respect, Pomae-maeaka which means mutual respect for dignity and Popia-piara which means caring for one another. The Family had a very important role in instilling the values of philosophy Bhinci-bhinciki Kuli as a foundation of character through habituation and modelling since early childhood in daily life were accustomed and modelling Poma-masiaka mutual love, Poangka-kataka which means mutual respect, Pomae-maeaka which means mutual respect for dignity and Popia-piara which means caring for one another. Application the philosophy values of Bhinci-bhinciki Kuli in early childhood was to instill the values morality, so that grow up with a personality that had good character.
\end{abstract}

Keywords: values; bhinci-bhinciki kuli; early childhood

\begin{abstract}
Abstrak
Penelitian ini bertujuan untuk mendeskripsikan implementasi nilai-nilai filosofi Bhinci-bhinciki kuli pada anak usia dini di masyarakat wolio. Jenis Penelitian ini menggunakan analisis deskriptif etnografi. Subjek dalam penelitian terdiri dari kepala suku dan toko budaya. Penelitian ini dilakukan di masyarakat wolio Buton. Metode pengumpulan data menggunakan panduan observasi dan wawancara. Berdasarkan hasil analisis data, menunjukan bahwa nilai-nilai prinsip hidup Bhinci-bhinciki kuli pada masyarakat buton meliputi Poma-masiaka artinya salaing menyayangi, mengasihi antara sesama, Poangka-kataka saling menghormati, Pomae-maeaka saling menjaga martabat, harga diri, dan Popia-piara artinya saling melindungi, membantu, berempati antara sesama. Keluarga memiliki peranan penting dalam menanamkan nilai-nilai ini sebagai dasar pendidikan karakter melalui pembiasaan dan keteladanan sejak usia dini dalam kehidupan sehari-hari yaitu dengan membiasakan dan mencotohkan perilaku saling menyayangi, menghormati antara sesama, saling menjaga martabat, saling melindungi, bekerjasama dan berempati. Penerapan nilainilai ini dapat membentuk anak menjadi pribadi yang berkarakter.
\end{abstract}

Kata Kunci : nilai; bhinci-bhinciki kuli; anak usia dini

Copyright (c) 2020 La Jeti, Manan, Kadar Risman, Edison

$\triangle$ Corresponding author :

Email Address : lajeti469@gmail.com (Jalan Anoa, kelurahan Waruruma, Kota Baubau, Sultra)

Received 6 July 2020, Accepted 12 July 2020, Published 17 July 2020 


\section{INTRODUCTION}

The philosophy values of "Bhinci bhinciki kuli" was the highest principle of life in Khalifatul Khamis country at the time. This philosophy contained noble values as the basis of human thinking and acting in realizing civil society. These values include Poma-masiaka, poangka-kataka, popia-piara, pomae-maeka. Currently, our society is experiencing a crisis of morality caused by a lack of knowledge, understanding, application of the values of "Bhinci bhinciki kuli" in the family and global challenges marked by technological developments. The moral crisis that engages the nation's generation includes the misuse of narcotics and drugs, theft, immoral acts, to brawl between groups, most of the perpetrators are adolescents.

Based on research results of (Raman et al., 2014) concluded that knowledge about culture as the basis of life had a good impact on children's development. These cultural values could also provide knowledge about childcare. Early childhood is a potential age that has the ability to absorb information mainly through language in the environment. On other hand, early childhood has a period time that is very sensitive to various information in their environment. At this age, children have an intellectual capacity of $80 \%$, which means that children have a strong grasp of the information obtained. In her theory, Maria Montessori said that children at an early age have a quick absorption or better known as the Absorbent Mind (Montessori, 1959) Information that enters through the child's senses is quickly absorbed into the brain. A child's brain's absorption can be compared to a sponge that absorbs water quickly therefore, educators should not be mistaken in providing concepts to children. Preparing a generation that is competitive through language and culture is the goal of the. United Nations Educational, Scientific and Cultural Organization (UNESCO).

Community is a group of families in a certain place. In group gave birth to a harmonious concept of social life. Concepts that are born included social norms, values, values, beliefs, rules and abligation. These values are instilled in the family to form a generation of character. The family is a system that plays an important role in the inheritance of cultural values in generations. According to Berns (Zink et al., 2004: 91p) In the microsystem that is the family as a representative of cultural values, which socializes culture to children through interactions in the family and neighbors and society. Based on research results of (Trampe et al., 2015), concluded that the culture of positive interactions in the family environment has an influence on the development of positive emotional behavior, the more positive interaction in the family environment becomes a culture, the emotional behavior of children becomes more positive. Children are familiarized with pleasant communication, courtesy, and hugs, with a culture of good interaction in the family, so that eternal values can be engraved for this nation's generation. With this phenomenon parents should re-open pieces of the value of wisdom in the land of Buton, so that these values can be etched back in children from an early age for the hope of a nation of character. Because the easy generation is the successor to the nation, it is in their hands that this nation will advance together with global civilization. (Nishi et al., 2017) concluded that culture thcultural background of subjects in their real life affects the speed of cooperation decision making differentially in social environments.

According to (Dewantara, 2004) Cultural Values must be instilled in children from early childhood, cultural values could be a filter of foreign culture that threatened children's morality. The philosophy values of "Bhinci Bhinciki Kuli" today are only historical stories from the culture of people's life in their time. As the times are marked by civilization of science and technology, these values eroded by increasingly evolving era. As the times are marked by the civilization of science and technology, these values eroded by an increasingly evolving era.

The wolio children are born and grow in the land of a thousand fortresses but are increasingly threatened by the times, if the philosophical values of life do not become the principle of life and as a filter for foreign cultures that lurk the behavior of the current generation. then what happens is the emergence of a generation of conflict triggers in the community. By whom these values must be instilled the prime and the first are family. The family is the main implement the values of "Bhinci bhinciki kuli" in family life, and social since 
early age. At this time children are called by the term "the golden age" which is characterized by the ability of obsorbent mind that is the absorption of strong thoughts. This is where parents take the role as role models, examples and role models "ingarso sung tulodo". Based on the results of (Lamm et al., 2018) concluded that children's cognitive development varies depending on the culture in which the child lives. Culture plays an important role in the growth and cognitive development of children which can affect the behavior of children. Child development is determined how much cultural interaction is obtained by children in the family environment..

Poma-masiaka which means mutual love, Poangka-ngkataka which means mutual respect, Pomae-maeka which means mutual respect for dignity and Popia-piara which means caring for one another. These values need to be applied early with appropriate methods of child development. one method that can be applied is through the concept of Ki Hadjar Dewantoro (Sujiono, 2009) teachers and parents in providing education to their sons and daughters certainly had 3 concepts namely; Ingarso sung tulodo, meaning that both teacher and parent are role models or role models for their children. Ingmadyo mangun karso, also as a guide in providing instruction and Tut Wury Handayani, teachers and parents always provide motivation and encouragement to enthusiasm in developing children's potential. In addition, the method can be applied through habituation and modelling methods in both the family and school environment. While the research conducted by (Abulizi et al., 2017) The Children's behavior was influenced by the environment context, Parents interaction could shape and increased the child emotional.

Based on the results of interviews with Mr. La Umbu Zaadi (3/3/2019) said that the people of Buton Bhinci-bhinciki kuli Philosophy are character values instilled in children from an early age. But as the times evolve the values of character in society, especially in the family began to disappear due to the workload of parents, the lack of parental knowledge of these values, the lack of available references and advanced technology. By referring to the theories, concepts and research results of various enographic studies, as well as community phenomena, the researcher is motivated to analyze and elevate these values to become a cultural reference to the values of local character. The values contained in the philosophy "Bhinci-bhinciki kuli" could be known what the concept of values contained and how the implementation of these values in his time. This research aims to describe and analyze the application of the Bhinci-bhinciki Kuli philosophy at community in Buton society and what values are contained in philosophy of Bhinci-bhinciki Kuli.

\section{RESEARCH METHOD}

This research used ethnographic research with a qualitative approach that is a research method based on the philosophy of phenomenology, used to examine natural conditions of objects. The subject of research is the subject to be examined or expected information about matters relating to the problem under study, namely the person or whatever is the center of attention or research target subject of his research is chiefs. In this study the researchers used the following data collection tools Interview Technique. The analysis technique used is interactive model analysis namely data collection, 'data reduction, data presentation, and drawing conclusions during data collection.

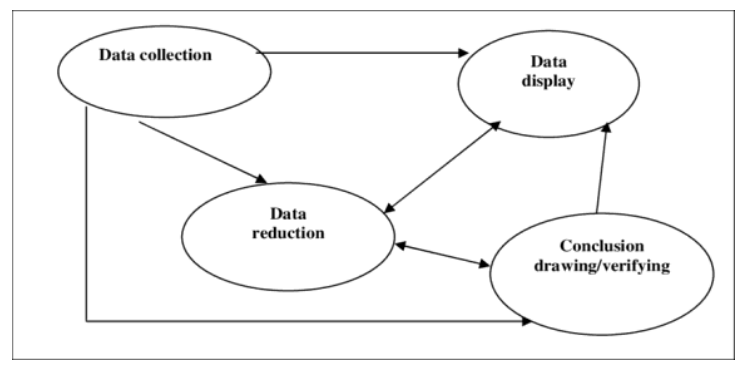

Data Analyze Miles and Huberman 


\section{RESULT AND DISCUSSION}

\section{The philosophy values of "Bhinci Bhinciki kuli"}

The philosophy values of "Bhinci bhinciki kuli" is the highest principle of life in buton community. In this philosophy contained noble values as the basis of human thinking and acting in realizing civil society. These values included Poma-masiaka, poangka-kataka, popiapiara, pomae-maeka). Currently, our society is experiencing a crisis of morality caused by a lack of knowledge, understanding, application of the values of "Bhinci bhinciki kuli" in the family and global challenges marked by technological developments. Based on law Number 23 of 2002 concerning Protection of Children's Rights. This Act seeks to protect children's rights from various forms of violence including trafficking, exploitation, child abuse, verbal abuse, physical abuse, intimidation, sexual abuse or other activities that can hinder children's growth and development. Because these various obstacles will only make it difficult for children to define their personal identity, character and life patterns in society, when they become adults. (Costa-Font et al., 2018) concluded that the culture had the social norms that shape the child behavior, through culture children had the personality indentity in social interaction. Culture is the principle of life the social community, so that need the strategy to implement in family life to instill since early childhood.

With a better approach, it is expected to provide objective values that can be applied to all opportunities for children to better approach, it is expected to provide objective values that can be applied to all opportunities for children to better understand people at all times. the context of a more mature, mature and wise. The values of philosophy Bhinci bhinciki kuli in accordance with devinition of (Sjarkawi \& Pd, 2006) Value meant that it was useful, capable, empowered, valid, and strong. Values is the quality of the a thing that made it likeable, desirable, useful, valued, and could be object of importance. According to the view of relativism : 1) Values are are relative because they relate to preferences (attitude, desires, dislike, feelings), 2). Values stand from different from one culture to another, 3). Judget like right and wrong, good, bad, 4) universal, absolute and objective Values that could be applied to all people at all times.

This definition is corroborated by results of research by (Kapitány et al., 2018) concluded that cultural values were living traditions, and contain socio-cultural values. Children who were raised with cultural rituals can form them as individuals who have social values in society. Cultural values of life adopted by ancestors that contain moral values, religion needs to be instilled in children from an early age through daily interactions in the family and social as theory (Bronfenbrenner, 1979: 5p) that the mycrosistem (family) environment provided an important role in their environment. This age is known as the golden age that has the potential of a child is developing rapidly. According to Montessori (Morrison, 2007) children of this age had the brains that were easy to absorb or are called absorbent minds. In addition, children also have a very sensitive period. Therefore, parents are expected to be able to apply optimal care and involvement with cultural values in certain communities so that they can develop all the potential of early childhood.

Based on research The values of "Bhinci bhinciki kuli" was the highest principle of life in Wolio community, this values included Poma-masiaka, Poangka-kataka, Popia-piara, Poangkakataka). In family life interaction parents as a model and habituation action in implementing Poma-masiaka which means mutual love, love friends, parents, brother and societies. Poangkakataka which means mutual respect, make polite in communication with parents, brother, friends and repect to the teacher and others. Pomae-maeaka which means mutual respect for dignity and Popia-piara which means caring for one another, help friends, help parents, brother and others. In this research that, the values of "Bhinci bhinciki kuli" must apply through habituation and modeling since early childhood. The values that instilled in aerly childhood would shape the children tobe good character and personality in the future.

The research was supported by Research conducted by (Raman et al., 2014) concluded that the pattern of life, the behavior of parents, educating children was influenced by cultural values understood by society. life of Indian society known as Maamuli culture socio-cultural 
studies that contained children used to interact with the value of moral values, childbirth ethics, patterns of , educating children, these values are understood in Latin Indian families. Maamuli cultural values have been applied by the ancestors, which contain moral values, religion so it needs to be instilled in children in India from an early age through daily interactions in family and social.

\section{Habituation}

Early childhood is a potential age, this age is known as the golden age which meant that children at this age had a lot of knowledge that made it easy to absorb information and construct it into knowledge. Some potentials of early childhood were: Absorbent mind with an absorbent brain, children made it easy to obtain various information from their environment. On the other hand the child also has a ZPD (Zone Proximally Development) meaning that the child has a certain space and time as a sensitive zone to be stimulated properly by his parents through habituation. Habituation was one of the steps or strategies of parents in the Wolio family to instill the values of Bhinci-bhiciki kuli. This habituation was a theory that was used to shape personality through good actions and strive to always be repeated because it gives a positive impact on someone's person and also others. This research supported by the research (Nielsen et al., 2012) concluded that the culture could be transmitted to shape the child's behavior through the habituation in playing.

This strategy was reinforced by Pavlov's theory (Santrock, 2007: 23p) that children's behavior can be formed through accustomed activities called "classical conditioning". With the conditions of behavior that are familiarized with both within the family, school and community, the child would grow into a person with good moral values. The noble values imprinted in the child were a form of behavior that is usually done in the family when building social interactions, adapting to the wider environment. (Escalante-Barrios et al., 2020) concluded that interaction The parent-child is a cornerstone of early childhood development and one-way early childhood programs can have a positive influence on early development.

In Wolio's family had a very important role in instilling cultural values of the BhinciBhinciki Kuli philosophy were values of character which should be passed from generation to generation with these values children would grow into civilized individuals, able to build harmonious social communication and be children, caring for children was influenced by responsible. Miana Wolio, in the sultanate era, cultural values understood by society. In the these values were highly valued in family life, socialized even in a government. Wolio children used to interact with the value of Poma-masiaka which means to love each other, Poangka-kataka which means mutual respect, Pomae-maeka which means mutual respect and for dignity and Popia-piara mutual help to help, protect and protect so that the civil society in its era can be realized. This research supported by the research (Gardner et al., 2018) concluded that the parenting behavior influenced the child behavior.

(Dewantara, 2004) Children have good values from an early age, so these values can lead children to become personal with good moral behavior, moral feelings, and moral knowledge. In everyday life children were accustomed to speak with courtesy, shared with peers, be guided to be responsible and be fair. Children who were accustomed to noble cultural values would grow up with personality that had character. According to (Bronfenbrenner, 1979) the mycrosystem environment which included the family had a very important role in the formation of character values. Good character values were formed in the family through interaction both incommunication and in moral actions. Results of Research conducted by (Metwally et al., 2016) that a good family culture had an influence on the development of emotional social behavior. Parents' knowledge of the importance of values in socio-cultural behavior was a determinant of children's emotional social behavior. Based on the description of the results of this study it could be concluded that cultivating interactions in the family and social with social values could influence the development of social behavioral values for children. 
Based on the results of research (Purzycki et al., 2018) that instilling cultural and moral values of religion could form the personality of a good child, children were able to position themselves well when interacting in a social environment. Therefore, good cultural values are the responsibility of the family to be passed on to generations, so that these values were cultivated in family life, and in society. According to (Dewantara, 2004) That civilization should be planted by the family early on. Adab values are studying character or character so that they are able to distinguish good and bad deeds that lead children to act in accordance with the understanding and habits experienced in their lives. As (Lickona, 2013) many situations habits are a factor forming moral behavior. William Bennett said that people who had good character act sincerely, loyal, courageous, virtuous, and just, even making the right choices unconsciously. They do the right thing because it's based on habits.

\section{Modelling}

Early childhood is a potential age, this age is known as the golden age which means that children at this age have a lot of knowledge that makes it easy to absorb information and construct it into knowledge. Some potentials of early childhood are: Absorbent mind with an absorbent brain, children make it easy to obtain various information from their environment. On the other hand, the child also had a ZPD (Zone Proximally Development) meaning that the child has a certain space and time as a sensitive zone to be stimulated properly by his parents. Modelling is one of the learning methods to shape learners' personalities. Through models of parenting are examples, examples or role models to be followed, emulated and imitated by children. both in the family and school environment. Parents on wolio in the past, made personal role models or role models.

The values of Bhinci-bhinciki kuli were imprinted in the family of the Wolio familily, parents paraphrasing the behavior of Poma-masika, Popia-piara, Poangka-kataka, Poamae-maeka to children. Mutual behavior poma-masiaka is seen and observed and even felt directly by the child when he is caring for, guided by both his parents, so that the child pays attention to the idolized figure, the resesarch conducted by (Fernández-Ballesteros et al., 2020) Concluded that good culture effect to behavior, children tobe friendly, competent and happiness, satisfaction and social participation.

The behavior of the Bhinci bhinciki kuli was imprinted in the child, then was applied in social interactions. According to Ki Hadjar Dewantoro(Sujiono, 2009: 126p) that teachers and parents in providing education in early childhood certainly must have 3 concepts namely; Ingarso sung tulodo, meaning that both teacher and parent are role models or role models for their children. Ingmadyo mangun karso built the spirit, also as a guide in providing instruction and Tut Wury Handayani, teachers and parents always provide motivation and encouragement to enthusiasm in developing children's potential. In addition, the method could be applied through habituation and modelling methods both in the school and family environment, beside that research conducted by (Gould et al., 2018) concluded that social culture must to instill through the action and teaching.

According to (Lickona, 2013) that parenting is the behavior of parents to discipline children and to make children responsible through guidance and assertiveness. The family is the first and foremost educator in a child's life, because it was from them that the child gets an education for the first time, as well as being the basis of children's development and children's lives later on. Pestalozzi (Morrison 1988: 46) said parents is the best teacher for his children. This means that the family provides the basis for the formation of behavior, character, morals, and education for children from an early age. Parent involvement could be interpreted as a parent's perception of his involvement in childcare in the form of active participation when playing and free time.

Research by (Atchley et al., 2011) , concluded that children could develop their moral social abilities, through direct teaching, modeling and learning by doing (learning by doing). So for teachers and parents should set a good example to develop children's social and moral abilities. Exemplary is the main key for parents to educate children to be a person of character. 
As stated by (Lickona, 2013) that values are captured, not taught means that good cultural values are captured by children through good modelling and taught through direct explanation.

\section{CONCLUSION}

Based on the results of the research, concluded that The values of "Bhinci Bhinciki Kuli" included Poma-masiaka which means mutual love, Poangka-kataka which means mutual respect, Pomae-maeaka which means mutual respect for dignity and Popia-piara which means caring for one another must be instilled since early childhood in family daily life, through habituation and modeling in daily life. The parents should accustomed and modelling Since early childhood to speak soft and polite words when talking to parents, older children and their age friends, please help, feel good, have the spirit of mutual cooperation, sympathy, empathy, and love to do humanitarian activities, in order to children grow up as the personality good character.

\section{ACKNOWLEDGMENT}

Alhamdulillahi rabil 'alamin, the researcher expresses the highest gratitude to Allah Subhanahu wa ta'alaa, for blessing, love, apportunity, health and mercy to complete this paper. Appreciation and thanks to Dr. Wa Ode Alzarliani, S.P.,M.M. as the Rector of Muhammadiyah Buton University who have given the support and motivation. Appreciation and thanks to Asma Kurniati, S.Pt.,M.Pd as the head of Early childhood study program who has given motivation. Appreciation and thanks to informan who have given the information for complete this research. Appreciation and thanks to Obsesi Journal as Publisher this paper.

\section{REFERENCES}

Abulizi, X., Pryor, L., Michel, G., Melchior, M., Van Der Waerden, J., \& EDEN Mother-Child Cohort Study Group. (2017). Temperament in infancy and behavioral and emotional problems at age 5.5: The EDEN mother-child cohort. PLoS One, 12(2), e0171971. doi:10.1371/journal.pone.0171971

Atchley, P., Atwood, S., \& Boulton, A. (2011). The choice to text and drive in younger drivers: Behavior may shape attitude. Accident Analysis \& Prevention, 43(1), 134-142. doi:10.1016/j.aap.2010.08.003

Bronfenbrenner, U. (1979). The ecology of human development. Harvard university press.

Costa-Font, J., Giuliano, P., \& Ozcan, B. (2018). The cultural origin of saving behavior. PloS One, 13(9), e0202290. https:// doi.org/10.1371/journal.pone.0202290

Dewantara, K. H. (2004). Ki Hadjar Dewantara Bagian Pertama: Pendidikan. Yogyakarta: Majelis Luhur Taman Siswa Endraswara.

Escalante-Barrios, E. L., Suarez-Enciso, S. M., Raikes, H., Davis, D., Garcia, A., Gonen, M., Veziroglu-Celik, M., \& Hazar, R. G. (2020). Child-parent interactions in American and Turkish families: Examining measurement invariance analysis of child-parent relationship scale. Plos One, 15(4), e0230831. https:// doi.org/10.1371/journal.pone.0230831

Fernández-Ballesteros, R., Olmos, R., Pérez-Ortiz, L., \& Sánchez-Izquierdo, M. (2020). Cultural aging stereotypes in European Countries: Are they a risk to Active Aging? Plos One, 15(5), e0232340. https://doi.org/10.1371/journal.pone.0232340

Gardner, F., Melendez-Torres, G., Knerr, W., \& Overbeek, G. (2018). Parenting behaviors that shape child compliance: A multilevel meta-analysis. https:// doi.org/10.1371/journal.pone.0204929

Gould, R. K., Krymkowski, D. H., \& Ardoin, N. M. (2018). The importance of culture in predicting environmental behavior in middle school students on Hawai'i Island. PloS One, 13(11), e0207087. https:// doi.org/10.1371/journal.pone.0207087 
DOI: 10.31004/obsesi.v5i1.643

Kapitány, R., Davis, J. T., Legare, C., \& Nielsen, M. (2018). An experimental examination of object-directed ritualized action in children across two cultures. Plos One, 13(11), e0206884. $\square$ https://doi.org/10.1371/journal.pone.0206884

Lamm, B., Keller, H., Teiser, J., Gudi, H., Yovsi, R. D., Freitag, C., Poloczek, S., Fassbender, I., Suhrke, J., \& Teubert, M. (2018). Waiting for the second treat: Developing culture-specific modes of self-regulation. Child Development, 89(3), e261-e277. https://doi.org/10.1111/cdev.12847

Lickona, T. (2013). Pendidikan karakter: Panduan lengkap mendidik siswa menjadi pintar dan baik. Bandung: Nusa Media.

Metwally, A. M., Salah El-Din, E. M., Shehata, M. A., Shaalan, A., El Etreby, L. A., Kandeel, W. A., Shaaban, S. Y., \& Rabah, T. M. (2016). Early life predictors of socio-emotional development in a sample of Egyptian infants. PloS One, 11(7), e0158086. https://doi.org/10.1371/journal.pone.0158086

Montessori, M. (1959). The absorbent mind. Lulu. com.

Morrison, G. S. (2007). Early childhood education today. Kevin M. Davis.

Nielsen, M., Cucchiaro, J., \& Mohamedally, J. (2012). When the transmission of culture is child's play. PLoS One, 7(3), e34066.https://doi.org/10.1371/journal.pone.0034066

Nishi, A., Christakis, N. A., \& Rand, D. G. (2017). Cooperation, decision time, and culture: Online experiments with American and Indian participants. PloS One, 12(2), e0171252. https:// doi.org/10.1371/journal.pone.0171252

Purzycki, B. G., Pisor, A. C., Apicella, C., Atkinson, Q., Cohen, E., Henrich, J., McElreath, R., McNamara, R. A., Norenzayan, A., \& Willard, A. K. (2018). The cognitive and cultural foundations of moral behavior. Evolution and Human Behavior, 39(5), 490-501. https://doi.org/10.1016/j.evolhumbehav.2018.04.004

Raman, S., Srinivasan, K., Kurpad, A., Dwarkanath, P., Ritchie, J., \& Worth, H. (2014). 'My Mother... My Sisters... and My Friends': Sources of maternal support in the perinatal period in urban India. Midwifery, 30(1), 130-137. https://doi.org/10.1016/j.midw.2013.03.003

Santrock, J. W. (2007). Perkembangan anak. Jakarta: Erlangga, 1(2), 3.

Sjarkawi, D., \& Pd, M. (2006). Pembentukan kepribadian anak.

Sujiono, Y. N. (2009). Konsep dasar pendidikan anak usia dini.

Trampe, D., Quoidbach, J., \& Taquet, M. (2015). Emotions in everyday life. PloS One, 10(12), e0145450. https:// doi.org/10.1371/journal.pone.0145450

Zink, C. F., Pagnoni, G., Martin-Skurski, M. E., Chappelow, J. C., \& Berns, G. S. (2004). Human striatal responses to monetary reward depend on saliency. Neuron, 42(3), 509-517. https://doi.org/10.1016/S0896-6273(04)00183-7 